\title{
Relationship between Tertiary Lymphoid Structure and the Prognosis and Clinicopathologic Characteristics in Solid Tumors
}

\author{
Zhan Zhao ${ }^{*}$, Hui Ding1 ${ }^{*}$, Zheng-bin Lin ${ }^{1}$, Sheng-hui Qiu1, Yi-ran Zhang1, Yan-guan Guo ${ }^{1}$, Xiao-dong Chu ${ }^{1}$, \\ Loi I Sam², Jing-hua Pan ${ }^{1 凶}$, Yun-long Pan ${ }^{1 凶}$ \\ 1. Department of General Surgery, the First Affiliated Hospital of Jinan University, Guangzhou 510632, China. \\ 2. International School, Jinan University, Guangzhou 510632, China. \\ * These authors contributed equally. \\ $\square$ Corresponding authors: Dr. Jing-hua Pan, MD, PhD., E-mail: huajanve@foxmail.com; Prof. Yun-long Pan, PhD., E-mail: tpanyl@jnu.edu.cn. \\ (c) The author(s). This is an open access article distributed under the terms of the Creative Commons Attribution License (https://creativecommons.org/licenses/by/4.0/).
} See http://ivyspring.com/terms for full terms and conditions.

Received: 2020.11.24; Accepted: 2021.03.21; Published: 2021.04.07

\begin{abstract}
Background: An increasing number of studies had shown that tertiary lymphoid structure (TLS) plays an important role in tumor progression. However, the prognostic role of TLS in various tumors remains controversial. This meta-analysis aims to investigate the clinicopathological and prognostic values of TLS in solid tumors.

Methods: A systematic search was conducted in PubMed, EMBASE and Cochrane Library undated to November 2, 2020. Odds ratios of clinical parameters, hazard ratio (HR) of overall survival (OS), relapse-free survival (RFS), disease-free survival (DFS) and relapse rate were calculated in order to evaluate the relationship between TLS expression and clinicopathological or prognostic values in different tumors.

Result: 27 eligible studies including 6647 patients with different types of tumors were analyzed. High TLS expression was associated with a longer OS $(\mathrm{HR}=0.66,95 \% \mathrm{Cl}: 0.50-0.86, P=0.002)$ and $\mathrm{RFS}(\mathrm{HR}=0.61,95 \%$ $\mathrm{Cl}: 0.47-0.79, P=0.0001)$. Moreover, high TLS levels in tumor were associated with a low risk of recurrence $(\mathrm{HR}=0.43,95 \% \mathrm{Cl}: 0.32-0.57, P<0.0001)$. However, there was no relationship between TLS expression and DFS. Meanwhile, high TLS expression was associated with smaller tumor size $(P<0.00001)$ and higher tumor infiltrating lymphocytes (TILs). Furthermore, the subgroup analysis showed high TLS expression that may be associated with a lower clinical grading and $\mathrm{N}$ stage in breast cancer and colorectal cancer.

Conclusion: High TLS expression is associated with the longer OS and RFS in solid tumors, and a lower risk of cancer relapse. Meanwhile, high TLS expression is also associated with a smaller tumor size, higher infiltration of TILs, lower clinical grading and $\mathrm{N}$ stage in the tumor. Therefore, high TLS expression in the tumor is a favorable prognostic biomarker for solid tumor patients.
\end{abstract}

Key words: tertiary lymphoid structure (TLS); tumor; overall survival; disease-free survival; relapse-free survival; clinicopathologic characteristics.

\section{Introduction}

Worldwide data suggests that the incidence and mortality of cancer are rapidly increasing over the past decades. Cancer is expected to be the leading cause of death and one of the major obstacles to prolong life expectancy [1]. Conventional therapies including radiotherapy and chemotherapy have limited therapeutic effects. Immunotherapy, a novel strategy for cancer treatment, has achieved significant success [2]. However, the limited numbers of biomarkers are difficult to predict and evaluate the therapeutic response of immunotherapy. Although programmed cell death-ligand 1 (PD-L1), deficient mismatch repair (dMMR) / microsatellite instability -high (MSI-H) and tumor mutational burden (TMB) had been considered as immunotherapy biomarkers. However, exploring more precise biomarkers is still a research focus for immunotherapy. 
Tertiary lymphoid structure (TLS) is a crucial element of the tumor immune microenvironment (TIME), which consists of T cells, B cells, fibroblastic reticular cell (FRC) network, high endothelial venules (HEVs) and follicular dendritic cells (FDCs) [3-6]. Recently, some studies had proved that TLS play an important role in different kinds of tumor [7-9]. TLS has been shown to improve the effect of immunotherapy and patient survival in various tumors due to its relation with immune cell infiltration in melanoma $[10,11]$. On the one hand, peritumoral TLS expression indicates unfavorable clinicopathological characteristics and a worse prognosis in hepatocellular carcinoma [12-14]. However, some studies also reported no association between TLS expression and overall survival in breast cancer $[9,15]$. Therefore, the relationship between TLS expression and clinicopathological characteristics and prognosis of the tumor still remains controversial.

This meta-analysis aims to investigate the clinicopathological characteristics and prognostic value of TLS expression in solid tumors based on published research.

\section{Materials and Methods}

\section{Search identification}

PubMed, EMBASE and Cochrane library was searched up to November 15, 2020 for primary studies, focusing on the relationship between TLS and human colorectal cancer. We designed a strategy consisting of Medical Subject Headings (MeSH), common keywords and their comprehensive combination to strengthen the sensitivity of the search. The following MeSH and common keywords were included: 'Tertiary Lymphoid Structure', 'Lymphoid Structures, Tertiary', 'Tertiary Lymphoid Organ', 'Ectopic Lymphoid Like Structure', 'Ectopic Lymphoid Organ', 'Tertiary Lymphoid Tissue', 'Ectopic Lymphoid Follicle', 'Ectopic Lymphoid Formations', 'Neoplasms', 'Tumors', 'Neoplasia', 'Cancer', 'Malignancy'. Randomly combing the MeSH terminology and relevant keywords ensures that the most comprehensive data were acquired. No language restriction was applied.

\section{Inclusion and exclusion criteria}

All eligible studies were initially screened by two authors (Z.Z and H.D) based on the title and abstract, then those considered potentially relevant were retrieved for full-text review. Any disagreement was resolved by discussion with a third author (J.P). The inclusion criteria were as follows: (1) Studies focused on patients with solid tumor and TLS expression; (2) Differential expressions of TLS in cancer tissue compared to adjacent non-cancerous tissue must be presented; (3) TLS were measured by a standard method; (4) The relationship between TLS expression and its clinical outcome with hazard ratios (HRs) of 95\% CI from each study could be extracted; (5) Studies included relationship between TLS expression and clinicopathological characteristics.

The exclusion criteria were as follows: (1) case reports, reviews, literature interpretations, personal view, grey literature; (2) The same data has been used in other studies; (3) Lack of clinical features and prognostic data.

\section{Data extraction}

According to PRISMA, two researchers (Z.Z and H.D) extracted data from all the included literature independently and any disagreement was resolved by a consensus with the third author (J.P) [16, 17]. The following data were extracted: first author, year of publication, country, types of tumors, number of patients, gender, age, expressions of Ki67, Cut-off criteria, TMN stage, clinical stage, detection of TLS, survival analysis, follow-up time, cut-off criteria; prognostic outcomes including HRs of high TLS expression for overall survival (OS), relapse-free survival (RFS), disease-free survival (DFS), relapse rate. If the literature just provided Kaplan-Meier curves, we estimated the statistics by Engauge Digitizer version 4.1 and utilize the spreadsheet developed by Jayne F Tierney for data extraction [18, 19] (Table 1 and Table 2).

\section{Quality assessment}

The above studies were evaluated independently by two researchers (L.Z and X.C) using the Newcastle-Ottawa Scale (NOS) [20]. The score was calculated based on three factors: selection, comparability and outcome, with a full score of 9 . The included studies with a score greater than 6 is considered as high quality [19]. The quality of the included studies in the current meta-analysis was high, with a score of not less than 6 per article (Table 1) $[7-9,12,13,15$, 21-41].

\section{Statistical analysis}

In our research, the prognostic value of TLS expression in patients with various tumors was assessed by the pooled HRs and its relevant 95\% CIs. A pooled HRs $>1$ implied a worse survival with high expressions of TLS, while HRs $<1$ indicated a favorable outcome. Odds ratio (OR) and the corresponding 95\% CIs were used to analyze the association between TLS expression and its clinicopathological characteristics. In addition, the heterogeneity between literature with $P$-value and $I^{2}$ were estimated. If $I^{2}>50 \%$ or $P<0.1$, it is believed that the studies exhibit obvious heterogeneity and a 
random-effect model was applied. Otherwise, if $I^{2}<$ $50 \%$ or $P>0.1$, fix-effects model was used. Subgroup analysis was then performed to investigate the source of heterogeneity. Subsequently, funnel plot was conducted to detect the publication bias. $P<0.05$ was considered statistically significant in all tests. All statistical analysis was done by Review Manager 5.3.

Table 1. Characteristics of included studies.

\begin{tabular}{|c|c|c|c|c|c|c|c|c|c|c|c|}
\hline First author & Year & Country & $\begin{array}{l}\text { Types of } \\
\text { tumor }\end{array}$ & Stage & $\begin{array}{l}\text { Sample } \\
\text { size }\end{array}$ & $\begin{array}{l}\text { Laboratory } \\
\text { method }\end{array}$ & Cut-off criteria & $\begin{array}{l}\text { Estimate } \\
\text { criteria }\end{array}$ & Follow-up time & $\begin{array}{l}\text { Survival } \\
\text { analysis }\end{array}$ & $\begin{array}{l}\text { NOS } \\
\text { score }\end{array}$ \\
\hline Zhao Y. & 2020 & China & ESCC & I & 593 & $\mathrm{HE}$ & $\begin{array}{l}\text { positive and } \\
\text { negative }\end{array}$ & TLS & $\begin{array}{l}\text { Median:42months (1 - } 102 \\
\text { months) }\end{array}$ & OS & 7 \\
\hline Zhang W.H. & 2020 & China & PDC & G1-G2 & 307 & IHC & $\begin{array}{l}\text { presence and } \\
\text { the location of } \\
\text { TLS }\end{array}$ & $\begin{array}{l}\text { B cell, FDC, T } \\
\text { cell }\end{array}$ & $\begin{array}{l}\text { RFS: median: } 39 \text { months ( } 1.5 \\
\text { - } 95.0 \text { months) OS: } 58 \\
\text { months (10.0 - } 96.0 \text { months). }\end{array}$ & OS, RFS & 9 \\
\hline $\begin{array}{l}\text { Yamaguchi } \\
\text { Y. }\end{array}$ & 2020 & Japan & CRC & II-III & 67 & IHC & number of TLS & TLS & $\begin{array}{l}\text { Median: } 42.9 \text { months }(22.5 \text { - } \\
73.4 \text { months) }\end{array}$ & Relapse & 8 \\
\hline Lin $Q$. & 2020 & China & GT & NR & 187 & IHC & $\begin{array}{l}\text { positive and } \\
\text { negative }\end{array}$ & TILs & more than 100 months & OS, TTR & 8 \\
\hline Li H. & 2020 & China & $\mathrm{HCC}$ & I-IV & 462 & IHC & $\begin{array}{l}\text { positive and } \\
\text { negative }\end{array}$ & TILs & $\begin{array}{l}\text { Median: } 61.3 \text { months (1.5 - } \\
119.4 \text { months) }\end{array}$ & OS, RFS & 8 \\
\hline Yoshihito Y. & 2020 & Japan & GT & I-IV & 226 & IHC & $\begin{array}{l}\text { percentage area } \\
(3 \%)\end{array}$ & $\begin{array}{l}\text { B cell, FDC, T } \\
\text { cell, HEV }\end{array}$ & more than 80 months & DFS & 7 \\
\hline He W. & 2020 & China & GT & I-III & 1033 & $\mathrm{IHC} / \mathrm{HE}$ & $\begin{array}{l}\text { positive and } \\
\text { negative }\end{array}$ & HEVFDC & more than 100 months & OS & 8 \\
\hline Li Q. & 2020 & China & OSCC & I-IV & 168 & $\mathrm{IHC} / \mathrm{HE}$ & $\begin{array}{l}\text { positive and } \\
\text { negative }\end{array}$ & $\begin{array}{l}\mathrm{HEV} \text {, Immune } \\
\text { cell }\end{array}$ & 5 years & OS, RFS & 8 \\
\hline Chao X. & 2020 & China & $\mathrm{BC}$ & NR & 60 & IHC & $\begin{array}{l}\text { positive and } \\
\text { negative }\end{array}$ & $\begin{array}{l}\text { B cell, FDC, T } \\
\text { cell HEV }\end{array}$ & $\begin{array}{l}\text { Median:48months (22 - } 163 \\
\text { months) }\end{array}$ & OS & 8 \\
\hline Li K. & 2020 & China & OsCC & NR & 65 & $\mathrm{IHC} / \mathrm{HE}$ & $\begin{array}{l}\text { locations and } \\
\text { counts of TLS } \\
(\mathrm{n}=4)\end{array}$ & $\begin{array}{l}\text { B cell, FDC, T } \\
\text { cell HEV }\end{array}$ & $\begin{array}{l}\text { Median: } 44 \text { months }(1-83 \\
\text { months) }\end{array}$ & OS, DFS & 8 \\
\hline $\begin{array}{l}\text { Sofopoulos } \\
\text { M. }\end{array}$ & 2019 & Greece & $\mathrm{BC}$ & NR & 112 & IHC & $\begin{array}{l}\text { locations and } \\
\text { counts of TLS }\end{array}$ & $\begin{array}{l}\mathrm{HEV} \text {, Immune } \\
\text { cell }\end{array}$ & $0-10$ years & OS, DFS & 7 \\
\hline Lee $\mathrm{M}$. & 2019 & Korea & $\mathrm{BC}$ & $\mathrm{I}-\mathrm{V}$ & 335 & $\mathrm{IHC} / \mathrm{HE}$ & $\begin{array}{l}\text { positive and } \\
\text { negative }\end{array}$ & $\begin{array}{l}\text { HEV, Immune } \\
\text { cell }\end{array}$ & NR & OS & 8 \\
\hline $\begin{array}{l}\text { Kuwabara } \\
\text { S. }\end{array}$ & 2019 & Japan & PDC & I-IV & 47 & $\mathrm{IHC} / \mathrm{HC}$ & area of TLS & $\begin{array}{l}\text { HEV, Immune } \\
\text { cell }\end{array}$ & Median: 749.5 days & OS & 8 \\
\hline Calderaro J. & 2019 & France & $\mathrm{HCC}$ & $\begin{array}{l}\text { BCLC } \\
\text { stage } \\
\text { B-C }\end{array}$ & 498 & $\mathrm{HE}$ & $\begin{array}{l}\text { positive and } \\
\text { negative }\end{array}$ & TLS & $0-24$ months & Relapse & 8 \\
\hline $\begin{array}{l}\text { Trajkovski } \\
\text { G. }\end{array}$ & 2018 & Yugoslavia & CRC & I-IV & 103 & IHC & $\begin{array}{l}\text { positive and } \\
\text { negative }\end{array}$ & TILs & NR & NR & 6 \\
\hline Posch F. & 2018 & Austria & CRC & II-III & 109 & IF & number of TLS & TLS & $0-36$ months & Relapse & 7 \\
\hline Song I. H. & 2017 & Korea & $\mathrm{BC}$ & I-IV & 108 & IHC & $\begin{array}{l}\text { positive and } \\
\text { negative }\end{array}$ & HEV & $\begin{array}{l}\text { Median:34.9 months (12.0 - } \\
55.8 \text { months) }\end{array}$ & DFS & 9 \\
\hline Liu X. & 2017 & China & $\mathrm{BC}$ & I-IV & 245 & $\mathrm{HE}$ & $\begin{array}{l}\text { within } 5 \mathrm{~mm} \\
\text { TLS }\end{array}$ & TLS & $\begin{array}{l}\text { Median:78 months (1 - } 134 \\
\text { months) }\end{array}$ & DFS, OS & 8 \\
\hline Buisseret L. & 2017 & Canada & $\mathrm{BC}$ & I-III & 125 & IHC & $\begin{array}{l}\text { positive and } \\
\text { negative }\end{array}$ & TLS & NR & NR & 6 \\
\hline $\begin{array}{l}\text { Schweiger } \\
\text { T. }\end{array}$ & 2016 & Vienna & CRC & I-IV & 57 & IHC & $\begin{array}{l}\text { positive and } \\
\text { negative }\end{array}$ & TLS & more than 80 months & OS, RFS & 9 \\
\hline Lee H. J. & 2016 & Korea & $\mathrm{BC}$ & I-III & 769 & IHC & $\begin{array}{l}\text { positive and } \\
\text { negative }\end{array}$ & HEV, TILs & more than 100 months & OS, DFS & 9 \\
\hline Silina K. & 2015 & Switzerland & $\mathrm{LC}$ & NA & 87 & $\mathrm{IHC}$ & $\begin{array}{l}\text { positive and } \\
\text { negative }\end{array}$ & TLS & 5 years & DFS & 6 \\
\hline Hiraoka N. & 2015 & Japan & PDC & I-IV & 308 & IHC & $\begin{array}{l}\text { positive and } \\
\text { negative }\end{array}$ & TLS & $\begin{array}{l}\text { Median:17.6 months (2.6 - } \\
201 \text { months) }\end{array}$ & OS, DFS & 9 \\
\hline $\begin{array}{l}\text { Figenschau } \\
\text { S. L. }\end{array}$ & 2015 & Norway & $\mathrm{BC}$ & I-III & 290 & IHC & $\begin{array}{l}\text { positive and } \\
\text { negative }\end{array}$ & TLS & NR & NR & 6 \\
\hline Di Caro G. & 2014 & Italy & CRC & II-III & 185 & IHC & $\begin{array}{l}\text { percentage area } \\
(2.68 \%)\end{array}$ & $\begin{array}{l}\text { TLS, TILs, } \\
\text { HEV }\end{array}$ & Median: 4.71 years & Relapse & 9 \\
\hline BehrD. S. & 2014 & Germany & $\begin{array}{l}\text { Merkel cell } \\
\text { carcinomas }\end{array}$ & I-IV & 21 & IHC & $\begin{array}{l}\text { positive and } \\
\text { negative }\end{array}$ & Immune cell & NR & OS, DFS & 7 \\
\hline Anna & 2014 & Norway & OSCC & I-IV & 80 & IHC & $\begin{array}{l}\text { within } 100 \text { um } \\
\text { TLS }\end{array}$ & $\begin{array}{l}\text { B cell, FDC, T } \\
\text { cell, HEV }\end{array}$ & more than 100 months & DSS & 8 \\
\hline
\end{tabular}


Table 2. Association between TLS expression and clinicopathological characteristics of tumor patients.

\begin{tabular}{|c|c|c|c|c|c|c|c|}
\hline \multirow[t]{2}{*}{ Clinicopathological parameter } & \multirow[t]{2}{*}{ Studies (n) } & \multirow[t]{2}{*}{ Patients (n) } & \multirow[t]{2}{*}{ OR $(95 \% \mathrm{CI})$} & \multirow[t]{2}{*}{ P-value } & \multicolumn{3}{|c|}{ Heterogeneity } \\
\hline & & & & & $\mathrm{I} \%$ & P-value & Model \\
\hline Age $<60$ vs. $>60$ years & 9 & 2593 & $0.91(0.76-1.11)$ & 0.36 & 18 & 0.28 & Fixed \\
\hline gastric tumor & 2 & 1101 & $1.17(0.85-1.60)$ & 0.33 & 45 & 0.18 & \\
\hline breast cancer & 2 & 407 & $0.98(0.61-1.59)$ & 0.94 & 0 & 0.42 & \\
\hline oral squamous cell carcinoma & 2 & 248 & $0.84(0.47-1.50)$ & 0.55 & 0 & 0.8 & \\
\hline pancreatic ductal carcinoma & 2 & 343 & $0.80(0.44-1.43)$ & 0.44 & 59 & 0.12 & \\
\hline other tumors & 1 & 494 & $0.69(0.48-1.00)$ & 0.05 & & & \\
\hline Gender (male vs. female) & 9 & 1772 & $1.11(0.87-1.41)$ & 0.40 & 16 & 0.30 & Fixed \\
\hline hepatocellular carcinoma & 2 & 894 & $1.11(0.76-1.60)$ & 0.6 & 63 & 0.1 & \\
\hline oral squamous cell carcinoma & 2 & 248 & $1.27(0.68-2.34)$ & 0.45 & 0 & 0.75 & \\
\hline pancreatic ductal carcinoma & 2 & 355 & $1.19(0.68-2.07)$ & 0.55 & 27 & 0.24 & \\
\hline other tumors & 3 & 275 & $0.97(0.58-1.61)$ & 0.89 & 64 & 0.06 & \\
\hline Tumor size (small vs. large) & 6 & 2555 & $1.52(1.27-1.81)$ & $<0.00001$ & 48 & 0.09 & Fixed \\
\hline hepatocellular carcinoma & 2 & 895 & $1.55(1.17-2.04)$ & 0.002 & 0 & 0.49 & \\
\hline gastric cancer & 2 & 1101 & $1.48(1.16-1.89)$ & 0.002 & 86 & 0.0007 & \\
\hline other tumors & 2 & 559 & $1.65(0.89-3.05)$ & 0.11 & 46 & 0.17 & \\
\hline ki67 expressions (low vs. high) & 3 & 509 & $0.71(0.29-1.75)$ & 0.46 & 79 & 0.009 & Random \\
\hline Tumor-infiltrating lymphocytes level (TILs) (low vs. high) & 3 & 635 & $0.15(0.10-0.21)$ & $<0.00001$ & 44 & 0.17 & Fixed \\
\hline breast cancer & 3 & 635 & $0.15(0.10-0.22)$ & $<0.00002$ & 44 & 0.17 & \\
\hline T stage (T1-T2 vs. T3-T4) & 8 & 1236 & $1.42(0.72-2.81)$ & 0.31 & 55 & 0.03 & Random \\
\hline colorectal cancer & 2 & 170 & $1.68(0.14-19.58)$ & 0.68 & 44 & 0.18 & \\
\hline oral squamous cell carcinoma & 2 & 237 & $1.48(0.16-13.54)$ & 0.73 & 85 & 0.01 & \\
\hline pancreatic ductal carcinoma & 2 & 355 & $3.51(1.06-11.63)$ & 0.04 & 0 & 0.52 & \\
\hline other tumors & 2 & 474 & $0.93(0.41-2.11)$ & 0.87 & 44 & 0.18 & \\
\hline N stage (N0 vs. >N0) & 9 & 1510 & $0.95(0.62-1.45)$ & 0.81 & 60 & 0.01 & Random \\
\hline colorectal cancer & 2 & 170 & $4.48(1.56-12.85)$ & 0.005 & 0 & 0.99 & \\
\hline breast cancer & 2 & 527 & $0.64(0.44-0.92)$ & 0.02 & 0 & 0.77 & \\
\hline oral squamous cell carcinoma & 2 & 232 & $0.90(0.16-4.89)$ & 0.9 & 79 & 0.03 & \\
\hline pancreatic ductal carcinoma & 2 & 355 & $0.97(0.40-2.34)$ & 0.94 & 43 & 0.19 & \\
\hline other tumors & 1 & 226 & $0.94(0.56-1.59)$ & 0.83 & & & \\
\hline M stage (M0 vs. M1) & 3 & 430 & $0.49(0.17-1.38)$ & 0.18 & 0 & 0.81 & Fixed \\
\hline pancreatic ductal carcinoma & 2 & 355 & $0.46(0.15-1.40)$ & 0.17 & 0 & 0.60 & \\
\hline other tumors & 1 & 75 & $0.91(0.04-23.43)$ & 0.96 & & & \\
\hline Grade (I-II vs. III-IV) & 11 & 2608 & $0.89(0.54-1.46)$ & 0.64 & 76 & $<0.00001$ & Random \\
\hline colorectal cancer & 2 & 170 & $8.64(2.48-30.09)$ & 0.0007 & 0 & 0.47 & \\
\hline breast cancer & 3 & 620 & $0.31(0.21-0.47)$ & $<0.00001$ & 0 & 0.38 & \\
\hline gastric tumor & 2 & 1140 & $0.87(0.69-1.10)$ & 0.26 & 0 & 0.91 & \\
\hline pancreatic ductal carcinoma & 2 & 355 & $2.22(0.62-7.92)$ & 0.22 & 0 & 0.76 & \\
\hline other tumors & 2 & 323 & $1.02(0.60-1.75)$ & 0.93 & 0 & 0.76 & \\
\hline
\end{tabular}

Abbreviations: vs: versus; T: primary tumor range; N: lymph node; M: distance metastasis; OR: odds ratios.

\section{Results}

Based on the above retrieval strategy, we initially identified 674 articles from the databases according to the keywords and excluded 123 duplicated articles. Among them, 336 articles were discarded after reviewing their abstracts or titles. The remaining articles were reviewed based on our inclusion criteria. Among the 215 articles, 146 were reviews or conference abstracts, so no relevant clinical data could be extracted; 27 articles did not provide enough data to generate relevant results; 13 articles were related to other leukocytes rather than TLS; 2 articles were author views or editorials. Finally, 27 eligible studies ( $\mathrm{n}=6647$ patients) were included in the current meta-analyses (Figure 1).

\section{Study characteristics}

The characteristics of the included articles are presented in Table 1. In our analysis, there were 5 studies focusing on colorectal cancer (CRC), 8 on breast cancer (BC), 2 on hepatocellular carcinoma (HCC), 3 on pancreatic tumor, 3 on gastric tumor (GT), 3 on oral squamous cell carcinoma (OSCC), 1 on esophageal squamous cell carcinoma (ESCC), Merkel cell carcinoma and lung squamous cell carcinoma (SCC) respectively. Clinical outcomes were assessed in 15 studies. Among them, 17 studies including 4748 patients used OS as the primary endpoint. 5 studies, including 1046 patients used relapse as the primary endpoint. 7 studies, including 1855 patients reported data on DFS. 4 studies, including 994 patients took RFS as the endpoint. The expressions of TLS were detected using the same method (immunohistochemistry) in most articles. Besides, we found that there were 5 studies with two different independent cohorts, which were included separately as independent cohorts for further statistics $[8,9,25,34$, 41]. 


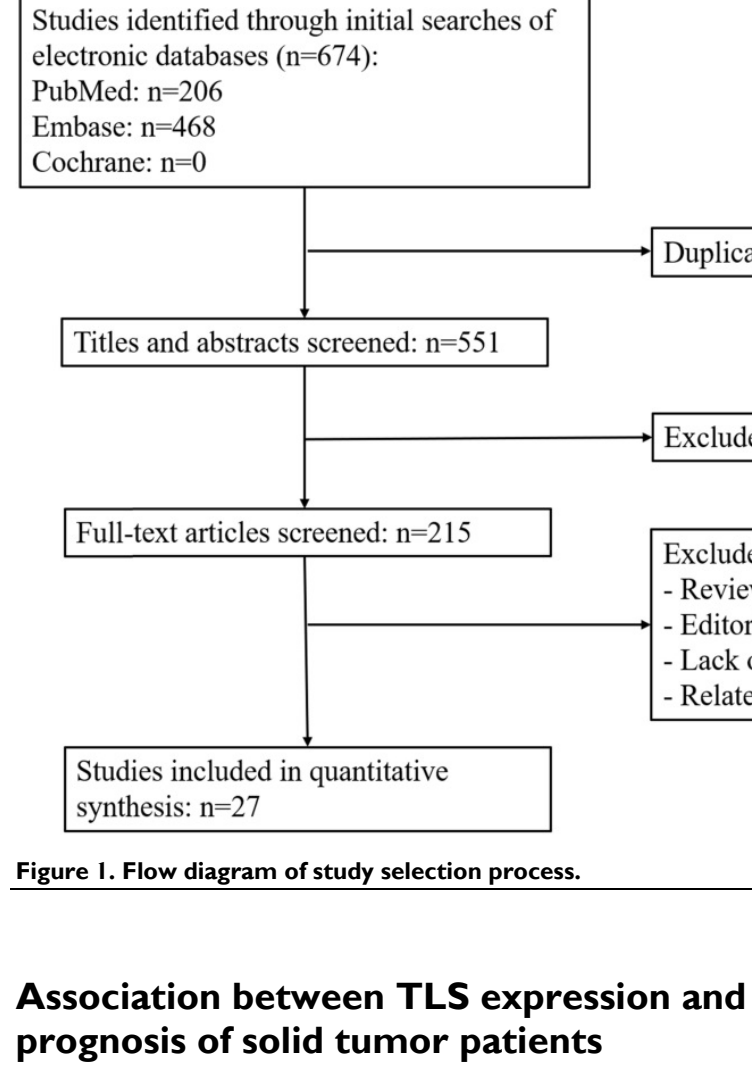

Studies included in quantitative synthesis: $\mathrm{n}=27$

Figure 1. Flow diagram of study selection process.

\section{Association between TLS expression and prognosis of solid tumor patients}

0.0001), which suggested that high TLS expression in the tumor were correlated with longer RFS compared with low or negative TLS expression in patients with tumor (Figure 3B). For the correlation between TLS expression and relapse rate of tumor, 5 studies including 821 patients were selected for analysis. The results showed that the pooled HRs of relapse rate in all patients were 0.43 (95\% CI: 0.32 - 0.57, $P<0.0001$ ), suggesting that high TLS expression was correlated with lower risk of recurrence compared with low or negative TLS expression in tumor patients. Subgroup analysis showed high TLS expression was correlated with lower relapse rate in CRC $(\mathrm{HRs}=0.43$,

We analyzed TLS expression within different types of cancer in 17 studies. Firstly, patient survival was evaluated by OS. The results showed that the pooled HRs of all patients with cancer was $0.60(95 \%$ CI: $0.46-0.78, P=0.0001$ ), suggesting that high TLS expression was correlated with longer OS in solid tumors. Furthermore, to assess the relationship between TLS expression and prognosis in a different type of tumors, the data were divided into five subgroups according to the tumor types. The pooled HRs for breast cancer OS was 0.77 (95\% CI: 0.40 - 1.45, $P=0.42)$, gastric cancer was 0.40 (95\% CI: $0.20-0.82, P$ $=0.01)$ and 0.31 for pancreatic cancer (95\% CI: 0.07 $1.28, P=0.11)$. For oral squamous cell carcinoma, OS was 0.35 (95\% CI: $0.16-0.75, P=0.007)$ and $0.77(95 \%$ CI: $0.61-0.98, P=0.03)$ for other cancer. Therefore, our results demonstrated that high TLS expression is correlated with better prognosis with GT and OSCC. However, subgroup analysis also indicated no correlation between TLS expression and OS in BC and pancreatic tumors (Figure 2).

Moreover, we also evaluated the role of TLS in DFS of solid patients. 7 studies with DFS data were showed that HRs in all tumor patients was 0.88 (95\% CI: $0.57-1.35, P=0.55)$, indicating that there was no relationship between TLS expression and DFS in tumor patients, especially in the breast cancer subgroup $(\mathrm{HR}=1.05,95 \% \mathrm{CI}: 0.55-2.00, P=0.89$ ) (Figure 3A). In addition, 4 studies focusing on RFS has a pooled HR of 0.57 (95\% CI: $0.45-0.72, P<$
95\% CI: $0.22-0.82, P=0.01)$ and other cancers (HRs = 0.43, 95\% CI: 0.31 - 0.59, $P<0.00001$ ) (Figure 3C).

\section{Association between TLS expression and clinical characteristics in solid tumors}

The relationship between TLS expression and clinicopathological characteristics are illustrated in Table 2. 11 studies [9, 15, 22-24, 29-32, 34, 35] displayed original data on the relationship between TLS expression and clinicopathological characteristics. For tumor growth, the pooled results showed that high TLS expression was significantly associated with smaller tumor size in overall solid tumors (OR: 1.52, 95\% CI: $1.27-1.81, P<0.00001)$, especially in the HCC (OR: 1.55, 95\% CI: $1.17-2.04, P$ $=0.002)$ and GC respectively (OR: 1.48, 95\% CI: 1.16 1.89, $P=0.002$ ) (Figure 4A). Moreover, low TLS expression in clinicopathological tissue were significantly associated with lower TILs in tumor (OR: 0.15, 95\% CI: 0.10 - 0.21, $P<0.00001$ ) (Figure 4B).

Besides, there were no significant correlation between TLS expression and the T stage (OR: 1.42, 95\% CI: $0.72-2.81, P=0.31$ ) (Figure 5A), N stage (OR: 0.95, 95\% CI: $0.62-1.45, P=0.81$ ) (Figure 5B) and clinical grade (OR: 0.89, 95\% CI: $0.54-1.46, P=0.64$ ) (Figure 4C). However, high TLS expression was associated with a lower clinical grade and a lower $\mathrm{N}$ stage in the colorectal cancer and breast cancer subgroup. Regarding the $\mathrm{T}$ stage, higher TLS expression had a positive correlation with a lower $\mathrm{T}$ stage in the pancreatic cancer subgroup. 


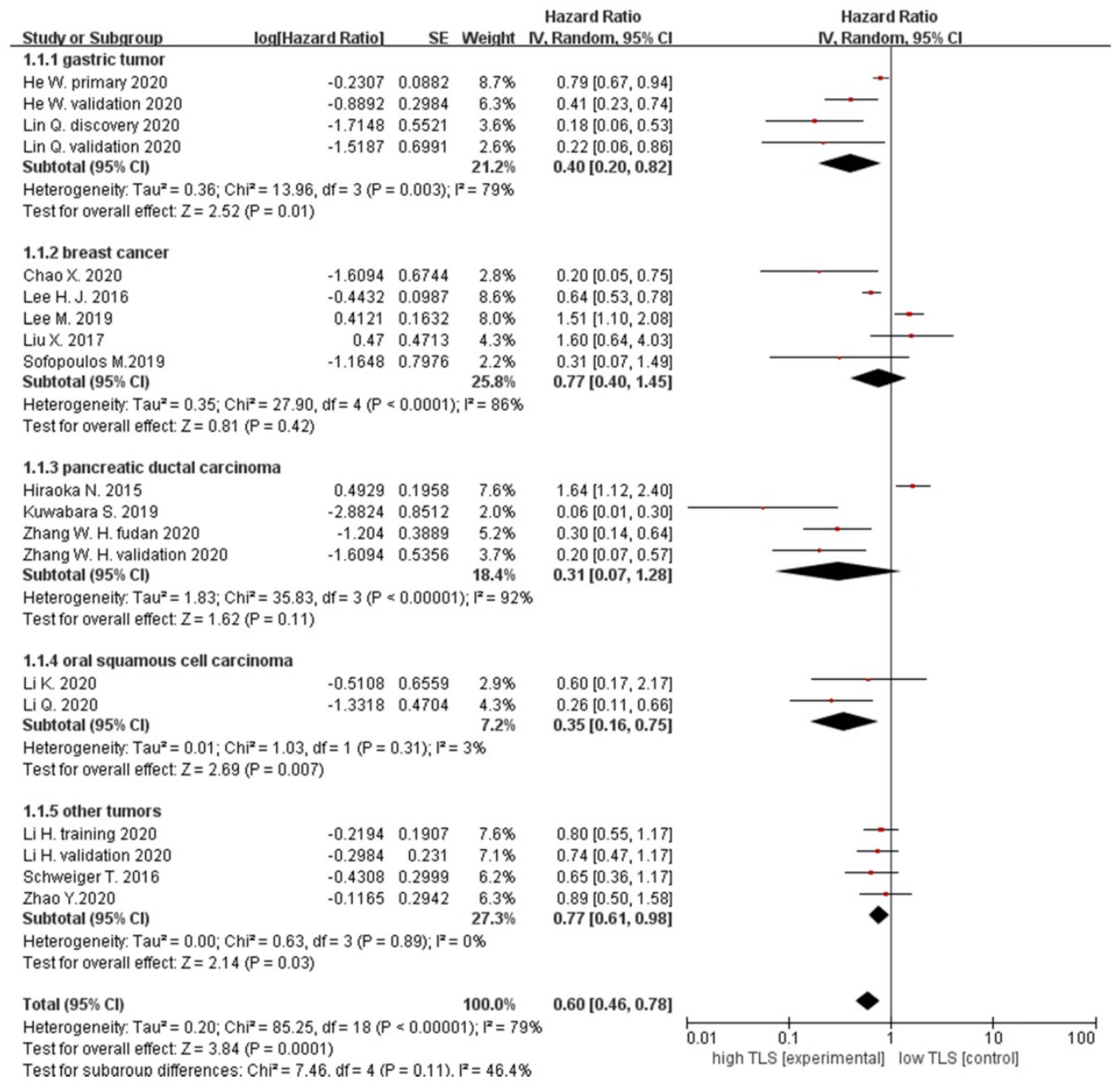

Figure 2. Forest plot for OS outcomes for different types of the tumor with TLS expression.

Finally, TLS expression were considered to have no relationship with the patient age (OR: 0.91, 95\% CI: $0.76-1.11, P=0.36$ ) (Supplementary Figure 1A), gender (OR: 1.11, 95\% CI: $0.87-1.41, P=0.40$ ) (Supplementary Figure 1B), expressions of ki67 (OR: 0.71 , 95\% CI: $0.29-1.75, P=0.46$ ) (Supplementary Figure 1C) and M stage (OR: 0.49, 95\% CI: 0.17 - 1.38, $P=0.18$ ) (Supplementary Figure 1D).

\section{Publication Bias}

We assessed the publication bias by funnel plots, as shown in Figure 4. There was no obvious publication bias for OS (Supplementary Figure 2A), DFS (Supplementary Figure 2B), RFS (Supplementary Figure 2C) and clinicopathological characteristics (Supplementary Figure 3).

\section{Discussion}

The crosstalk between tumor cells and tumor immune system has gained people attention for cancer immunotherapy including monoclonal antibodies, cancer vaccines and adoptive $\mathrm{T}$ cell therapy [42-44]. A large number of studies demonstrated that the tumor microenvironment is closely related to the prognosis and effectiveness of immunotherapy [45-47]. TLS is a crucial component of tumor immune microenvironment $[5,48]$, which not only facilitating the recruitment of immune cells or play an anti-tumor role, but also act as a predictor for the prognosis of various cancer $[4,7,10,15,22,24,34$, 39]. However, several studies reported the effect of TLS expression on prognosis and clinicopathological characteristics of solid tumor patient remains controversial $[9,11,13,15]$. To the best of our knowledge, this is the first comprehensive meta-analysis on the prognostic value and clinicopathological characteristics of TLS in various solid tumors. We provided strong evidence that high expression of TLS in tumor show a favorable prognostic value of tumor patients in terms of OS, RFS and relapse rate. Additionally, TLS expression is associated with tumor grade (especially in colorectal cancer and breast cancer), $\mathrm{T}$ stage (mainly in pancreatic cancer), $\mathrm{N}$ stage (particularly in colorectal cancer and breast cancer), tumor size (mostly in liver cancer and gastric cancer) and TILs (especially in breast cancer). 
Firstly, the prognostic value of TLS in tumor patients is evaluated systemically. Our finding revealed no significant correlation between the high expressions of TLS and DFS in tumor patients. However, patients with higher TLS expression have a longer OS, RFS and lower relapse rate. In the subgroup analysis of $O S$ in patients with gastric cancer and oral squamous cell carcinoma, patients with a higher TLS expression obviously have longer OS than those with a lower TLS expression. Nonetheless, the results in the breast cancer and pancreatic cancer subgroup showed that TLS expression has no relationship with OS. Using the same method to access the results of the DFS and relapse rate, no obvious correlation was obtained in the DFS subgroup. In the relapse subgroup, colorectal cancer patients with a higher TLS expression showed a lower risk of relapse. Therefore, we conclude that TLS expression is a prognostic biomarker for tumor patients in terms of OS and RFS, but not DFS. Meanwhile, TLS is also a biomarker for recurrence rate in tumor patients. Previous studies have found that the gene expression of TLS confirmed a prognostic role in melanoma, which are correlated with the gene of B cell, T cell, other types of immune cell and RNA-seq data for metastatic melanomas [49-52]. Meanwhile, the gene expression analysis of TLSs identified pathways regulating immune cell activation and trafficking, a suppressed regulatory $\mathrm{T}$ (Treg) cell induction pathway and an enhanced $\mathrm{T}$ helper 17 (TH17) cell-stimulating pathway correlating with improved survival [5].

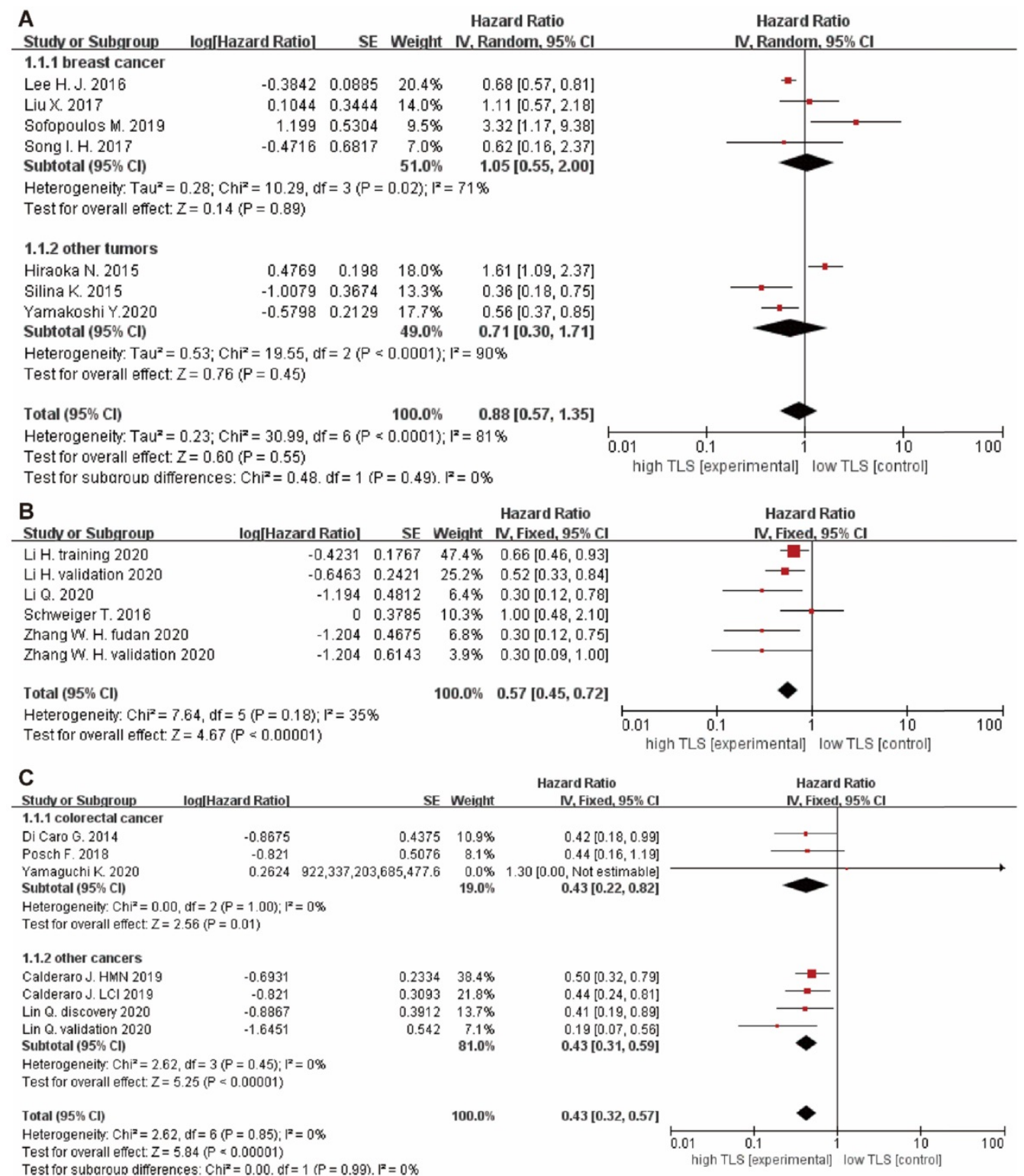

Figure 3. Forest plot for DFS, RFS and relapse rate analysis. (A) DFS outcome of cancer with high TLS expression versus low TLS expression. (B) RFS outcome of cancer with high TLS expression versus low TLS expression. (C) Relapse rate outcome of cancer with high TLS expression versus low TLS expression. Each result is shown by the HR with $95 \%$. 


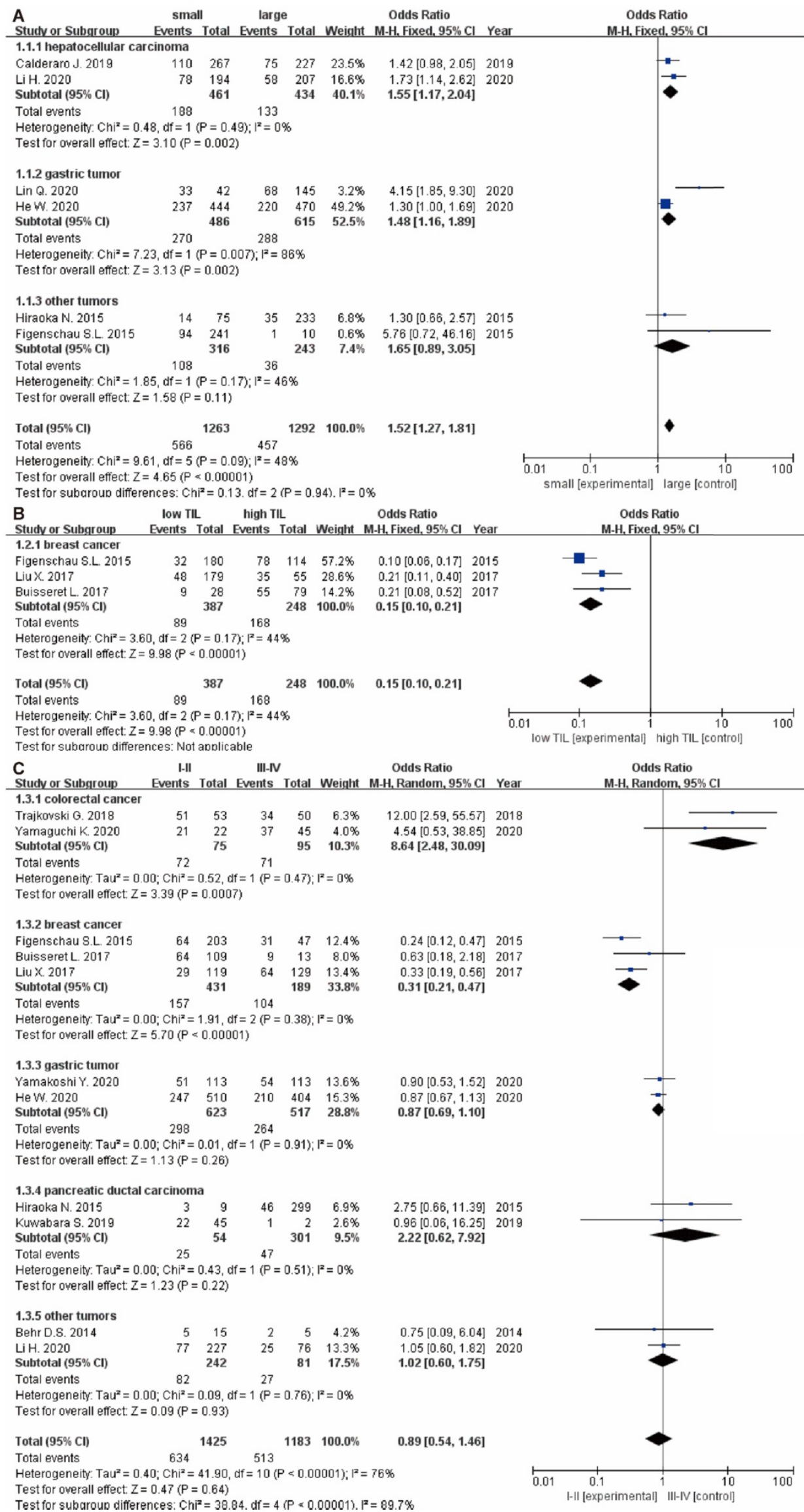

Figure 4. The forest plot of OR was assessed for association between TLS and clinicopathological characteristics. (A) tumor size; (B) TILs; (C) grade. Each result is shown by the OR with $95 \% \mathrm{Cl}$. 
A

Odds Rati

Odds Ratio

Studv or Subgroup Events Total Events Total Weight M-H, Random, 95\% CI

1.4.1 colorectal cancer

Trajkovski G. 2018

$\begin{array}{rrrrr}12 & 12 & 73 & 91 & 4.6 \% \\ 4 & 5 & 54 & 62 & 6.5 \%\end{array}$

$6.29[0.36,111.24]$

Yamaguchi K. 2020

Subtotal $(95 \% \mathrm{Cl})$

17

$153 \quad 11.2 \%$

$0.59[0.06,5.99]$

$\begin{array}{lll}\text { Total events } & 16 & 127 \\ \text { Heterogeneity: } \operatorname{Tau}^{2}=1.42 ; \mathrm{Ch}^{2}=1.80, \mathrm{df}=1(\mathrm{P}=0.18) ; \mathrm{I}^{2}=44 \%\end{array}$

Heterogeneity: Tau $^{2}=1.42 ; \mathrm{Chi}^{2}=1.80$,
Test for overall effect: $Z=0.41(P=0.68)$

1.4.2 oral squamous cell carcinoma

Li 2020

Wirsing A.M. 2014

Subtotal $(95 \% \mathrm{Cl})$

$\begin{array}{rr}70 & 102 \\ 15 & 46\end{array}$

102
46
48

$53 \quad 66 \quad 20.6 \%$

$1.68[0.14,19.58]$

Total events $\quad 85 \quad 55$

Heterogeneity: $\mathrm{Tau}^{2}=2.18 ; \mathrm{Chi}^{2}=6.54, \mathrm{df}=1(\mathrm{P}=0.01) ; \mathrm{I}^{2}=85 \%$

Test for overall effect: $Z=0.35(P=0.73$ )

1.4.3 pancreatic ductal carcinoma

Hiraoka N. 2015

Kuwabara S. 2019

Subtotal $(95 \% \mathrm{Cl})$

$\begin{array}{lcc}\text { Total events } & 8 & 64 \\ \text { Heterogeneity: } \mathrm{Tau}^{2}=0.00 ; \mathrm{Chi}^{2}=0.41, d f=1 & (P=0.52) ; \mathrm{I}^{2}=0 \%\end{array}$

$\begin{array}{lllll}3 & 9 & 46 & 299 & 12.4 \%\end{array}$

15

Test for overall effect: $Z=2.05(P=0.04)$

1.4.4 other tumors

LiuX. 2017

Yamakoshi Y. 2020

Subtotal $(95 \% \mathrm{Cl})$

Total events

$\begin{array}{rrrrr}89 & 233 & 4 & 15 & 15.0 \% \\ 30 & 74 & 75 & 152 & 22.9 \%\end{array}$

$1.70[0.53,5.50]$
$0.70[0.40,1.23]$

$2.75[0.66,11.39]$

$6.39[0.68,59.65]$

$0.54[0.26,1.12]$
$5.08[1.05,24.57]$

$1.48[0.16,13.54$

Heterogeneity. $\mathrm{Tau}^{2}=0.17 ; \mathrm{Chi}^{2}=1.79, \mathrm{df}=1(\mathrm{P}=0.18) ; \mathrm{I}^{2}=44 \%$

Test for overall effect: $Z=0.17(P=0.87)$

Total $(95 \%$ Cl)

487

Total events

228

$\begin{array}{lll}749 & 100.0 \%\end{array}$

$0.93[0.41,2.11]$

Heterogeneity: $\mathrm{Tau}^{\mathbf{z}}=0.44 ; \mathrm{Chi}^{\mathbf{z}}=15.66, \mathrm{df}=7(\mathrm{P}=0.03) ; \mathrm{I}^{\mathbf{2}}=55 \%$

Test for overall effect: $Z=1.02$ ( $P=0.31$ )

Test for subaroun differences: $\mathrm{Chi}^{2}=3.22 . \mathrm{df}=3(\mathrm{P}=0.36) . \mathrm{I}^{2}=6.8 \%$

$1.42[0.72,2.81]$

B

No

$>$ NO

Study or Subgroup Events Total Events Total Weight M-H, Random, 95\% Cl

1.5.1 colorectal cancer

Trajkovski G 2018

$\begin{array}{lllll}52 & 56 & 35 & 47 & 7.8 \% \\ 21 & 22 & 37 & 45 & 3.3 \%\end{array}$

Yamaguchi K. 2020

Subtotal $(95 \% \mathrm{CI})$

Total events

73

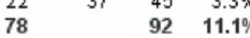

72

Heterogeneity: $\operatorname{Tau}^{2}=0.00 ; \mathrm{Chi}^{2}=0.00, \mathrm{df}=1(\mathrm{P}=0.99) ;\left.\right|^{2}=0 \%$

Test for overall effect: $Z=2.79(P=0.005)$

1.5.2 breast cancer

Figenschau S.L. 2015

Liu X. 2017

Subtotal $(95 \% \mathrm{Cl})$

Total events

$\begin{array}{lllll}70 & 200 & 40 & 85 & 16.1 \%\end{array}$

Heterogeneity Tau $^{2}=0.00 ; C h i=0.09, d f=1 \quad P=0$

Test for overall effect: $Z=2.38(P=0.02)$

1.5.3 oral squamous cell carcinoma

$\begin{array}{lrrrrr}\text { Li Q. } 2020 & 59 & 90 & 64 & 78 & 13.1 \% \\ \text { Wirsing A.M. 2014 } & 13 & 44 & 3 & 20 & 6.5 \% \\ \text { Subtotal (95\% Cl) } & & \mathbf{1 3 4} & & \mathbf{9 8} & \mathbf{1 9 . 7 \%} \\ \text { Total events } & 72 & & 67 & & \end{array}$

Heterogeneity: $\mathrm{Tau}^{2}=1.20 ; \mathrm{Chi}^{2}=4.78, \mathrm{df}=1(\mathrm{P}=0.03) ; \mathrm{|}^{2}=79 \%$

Test for overall effect: $Z=0.13(P=0.90)$

1.5.4 pancreatic ductal carcinoma

$\begin{array}{lrrrrr}\text { Hiraoka N. 2015 } & 11 & 56 & 38 & 252 & 12.8 \% \\ \text { Kuwabara S. 2019 } & 9 & 22 & 14 & 25 & 8.2 \% \\ \text { Subtotal (95\% Cl) } & & 78 & & 277 & \mathbf{2 1 . 1 \%} \\ \text { Total events } & 20 & & 52 & & \end{array}$

Total events

20

Test for overall effect: $Z=0.07(P=0.94)$

1.5.5 other tumors

Yamakoshi Y. 2020

Subtotal $(95 \% \mathrm{Cl})$

Total events

$54 \quad 118$

$\begin{array}{llll}118 & 51 & 108 & 16.0 \%\end{array}$

$108 \quad 16.0 \%$

Heterogeneity: Not applicable

Test for overall effect: $Z=0.22(P=0.83)$

Total $(95 \% \mathrm{Cl})$

Total events

$\begin{array}{llll}721 & 789 & 100.0 \%\end{array}$

Heterogeneity: $\mathrm{Tau}^{2}=0.22 ; \mathrm{Chi}^{2}=20.09, \mathrm{df}=8(\mathrm{P}=0.010) ; \mathrm{I}^{2}=60 \%$

Test for overall effect: $Z=0.24(P=0.81)$

Test for subaroun differences: $\mathrm{Chi}^{2}=12.08 . \mathrm{df}=4(\mathrm{P}=0.02) . \mathrm{I}^{2}=66.9 \%$

Odds Ratio

$4.46[1.33,14.95]$

$4.54[0.53,38.85]$

$4.48[1.56,12.85]$

$0.61[0.36,1.01]$ $0.68[0.40,1.14]$ $0.64[0.44,0.92]$

$0.42[0.20,0.86]$ $2.38[0.59,9.52]$ $0.90[0.16,4.89]$

$1.38[0.65,2.90]$ $0.54[0.17,1.74]$ $0.97[0.40,2.34]$

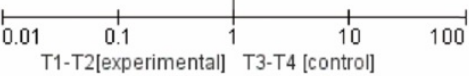

T1-T2[experimental] T3-T4 [control]

Odds Ratio M-H, Random, $95 \% \mathrm{Cl}$

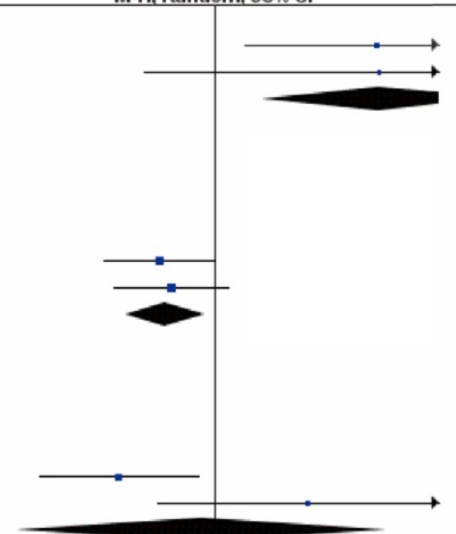

$0.94[0.56,1.59]$ $0.94[0.56,1.59]$

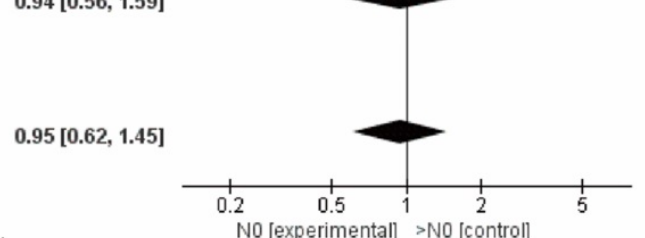

Figure 5. Forest plot of the association between TLS expression with clinicopathological characteristics. (A): T stage; (B): $N$ stage. 
To further evaluate the role of TLS in tumor progression, the relationship between TLS expression and clinicopathological characteristics in tumor patients were also analyzed and no significant association was found among TLS expression, age, gender, grade, ki67 expressions, $\mathrm{N}$ stage and $\mathrm{T}$ stage. However, in the subgroup of colorectal cancer and breast cancer, patient with lower $\mathrm{N}$ stage and clinical grade have higher expression of TLS in tumor tissue. Surprisingly, TLS expression is also correlated with the development of tumor size as indicated by the high TLS expression implies small tumor size especially in liver cancer and gastric tumor. Previous study has shown that the density of TLS plays an important role in the control of tumor growth in the elimination and equilibrium phase [32]. Our study also found that high TLS expression had a positive correlation with infiltration of TILs in tumor tissues, which might be associated with the TLS function. Previous studies have revealed the function of TLS to recruit TILs, such as T cell, B cell, DC cell, through HEV or some chemokines, which could improve its antitumor immunity [53]. As the part of TLS, HEV also can recruit TILs to defeat tumor cells by activating the nuclear factor $\mathrm{\kappa B}(\mathrm{NF}-\mathrm{kB})$ signaling pathway [54]. In addition, TILs have some connection with the checkpoint blockade immunotherapy [55]. That might mean that TLS plays an important role in immunotherapy. In our subgroup analysis, we found that in breast cancer patients, high TLS expression was associated with favorable clinicopathological characteristics (lower $\mathrm{N}$ stage, lower clinical grade and higher infiltration of TILs), indicating positive clinical outcome. However, there is no relationship between TLS expression and OS and DFS in the breast cancer subgroup. Therefore, further investigation is still required to explore the underlying mechanism. In addition, we also found that high TLS expression was related to a lower $\mathrm{T}$ stage, $\mathrm{N}$ stage and clinical grade in colorectal cancer. Previous study statistics showed that in colorectal cancer, increasing $\mathrm{T}$ stage was associated with a steady increase in rates of local recurrence. Meanwhile, the results of $\mathrm{N}$ stage also show that the increasing $\mathrm{N}$ stage was associated with the rising rate of 5-Year local recurrence [56]. Therefore, low $\mathrm{T}$ stage, $\mathrm{N}$ stage and clinical grade were associated with low relapse rate in colorectal cancer patients with high TLS expression. Furthermore, high TLS expression has many immune pathways that enhance anti-tumor efficacy, which may be an important factor in reducing relapse in patients. Consequently, the relapse rate is lower in colorectal cancer patients with high TLS expression. Therefore, further research is needed to figure out the function of TLS in the treatment of cancer.
There are several limitations to our meta-analysis. First of all, some survival statistics calculated from the survival curve using Engauge Digitizer might have a certain degree of deviation even though the data were extracted very carefully. Secondly, the amount of research done in the subgroup analysis of OS, DFS, RFS, relapse rate and the type of tumors were not enough, to some extent, which could affect our understanding of the role of TLS. Finally, there are some studies that detected the TLS using different parts of it, for instance, B cells, T cells and HEV, which may cause some biases in our results.

\section{Conclusion}

Despite the above-mentioned limitations, we have come to a conclusion that high TLS expression in the tumor is correlated with better OS in the oral squamous cell carcinoma and gastric tumor, better RFS and lower relapse rate. Meanwhile, TLS expression is related to tumor-infiltrating lymphocytes level and tumor size. In the subgroup of breast and colorectal cancer, high levels of TLS are overexpressed in cancer of low clinical grade and $\mathrm{N}$ stage. In summary, high expression of TLS is a potential prognostic marker in clinic for the assessment of patient survival and recurrence and its role in tumor immunotherapy is worth investigating in the future.

\section{Abbreviation}

ESCC: esophageal squamous cell carcinoma; CRC: colorectal cancer; GT: gastric tumors; HCC: hepatocellular carcinoma; BC: breast cancer; PDC: pancreatic ductal carcinoma; LC: lung cancer; IHC: immunohistochemistry; IF: immunofluorescence; H\&E: hematoxylin-eosin staining; NOS: the Newcastle-Ottawa Scale; OS: overall survival; DFS: disease-free survival; RFS: relapse-free survival; TILs: tumor infiltrating lymphocytes; TLS: tertiary lymphoid structure; HEV: high endothelial venules; TIME: tumor immune microenvironment; FRC: fibroblastic reticular cells; FDCs: follicular dendritic cells; MeSH: Medical Subject Headings; HR: hazard ratio; OR: odds ratios.

\section{Supplementary Material}

Supplementary figures.

http://www.medsci.org/v18p2327s1.pdf

\section{Acknowledgements}

\section{Data Availability Statement}

The datasets analyzed for this study are available from the corresponding author (J. P). 


\section{Funding}

This research was supported by the First Affiliated Hospital of Jinan University Flagship Specialty Construction Project-General Surgery (711003), the Guangdong Basic and Applied Basic Research Fund Project (2018A030313145; 2019A1515011763; 2019A1515110543) and the Fundamental Research Business Expenses of Central Universities (11620306).

\section{Author Contributions}

Y.P and J.P: research idea. Z.Z, H.D, Y.Z and Z.L: data extraction and integrated analysis. S.Q, Y.G, X.D, J.P: quality assessment and result interpretation. Z.Z: writing. Y.P and J.P: modification and polishing. All participants: final approval of manuscript.

\section{Competing Interests}

The authors declare that the research was conducted in the absence of any commercial or financial relationships that could be construed as a potential conflict of interest.

\section{References}

1. Bray F, Ferlay J, Soerjomataram I, Siegel RL, Torre LA, Jemal A. Global cancer statistics 2018: GLOBOCAN estimates of incidence and mortality worldwide for 36 cancers in 185 countries. CA Cancer J Clin. 2018; 68: 394-424.

2. Janakiram M, Pareek V, Cheng H, Narasimhulu DM, Zang X. Immune checkpoint blockade in human cancer therapy: lung cancer and hematologic malignancies. Immunotherapy. 2016; 8: 809-19.

3. Colbeck EJ, Ager A, Gallimore A, Jones GW. Tertiary Lymphoid Structures in Cancer: Drivers of Antitumor Immunity, Immunosuppression, or Bystander Sentinels in Disease? Front Immunol. 2017; 8: 1830

4. Helmink BA, Reddy SM, Gao J, Zhang S, Basar R, Thakur R, et al. B cells and tertiary lymphoid structures promote immunotherapy response. Nature. 2020; 577: 549-55.

5. Sautes-Fridman C, Petitprez F, Calderaro J, Fridman WH. Tertiary lymphoid structures in the era of cancer immunotherapy. Nat Rev Cancer. 2019; 19: $307-25$

6. Goc J, Fridman WH, Sautes-Fridman C, Dieu-Nosjean MC. Characteristics of tertiary lymphoid structures in primary cancers. Oncoimmunology. 2013; 2: e26836.

7. Zhao Y, Xu E, Yang X, Zhang Y, Chen H, Wang Y, et al. Tumor infiltrative growth pattern correlates with the immune microenvironment and is an independent factor for lymph node metastasis and prognosis in stage T1 esophageal squamous cell carcinoma. Virchows Archiv. 2020; 477: 401-8.

8. Lin $\mathrm{Q}$, Tao $\mathrm{P}$, Wang J, Ma L, Jiang $\mathrm{Q}$, Li J, et al. Tumor-associated tertiary lymphoid structure predicts postoperative outcomes in patients with primary gastrointestinal stromal tumors. Oncoimmunology. 2020; 9: 1747339.

9. Li H, Wang J, Liu H, Lan T, Xu L, Wang G, et al. Existence of intratumoral tertiary lymphoid structures is associated with immune cells infiltration and predicts better prognosis in early-stage hepatocellular carcinoma. Aging (Albany NY). 2020; 12: 3451-72.

10. Cabrita R, Lauss M, Sanna A, Donia M, Skaarup Larsen M, Mitra S, et al. Tertiary lymphoid structures improve immunotherapy and survival in melanoma. Nature. 2020; 577: 561-5

11. Petitprez F, de Reyniès A, Keung EZ, Chen TWW, Sun CM, Calderaro J, et al. B cells are associated with survival and immunotherapy response in sarcoma. Nature. 2020; 577: 556-60

12. Sofopoulos M, Fortis SP, Vaxevanis CK, Sotiriadou NN, Arnogiannaki N, Ardavanis A, et al. The prognostic significance of peritumoral tertiary lymphoid structures in breast cancer. Cancer Immunology, Immunotherapy. 2019; 68: 1733-45.

13. Lee M, Heo SH, Song IH, Rajayi H, Park HS, Park IA, et al. Presence of tertiary lymphoid structures determines the level of tumor-infiltrating lymphocytes in primary breast cancer and metastasis. Modern Pathology. 2019; 32: 70-80.

14. Finkin S, Yuan D, Stein I, Taniguchi K, Weber A, Unger K, et al. Ectopic lymphoid structures function as microniches for tumor progenitor cells in hepatocellular carcinoma. Nature Immunology. 2015; 16: 1235-44.

15. Liu X, Tsang JYS, Hlaing T, Hu J, Ni YB, Chan SK, et al. Distinct tertiary lymphoid structure associations and their prognostic relevance in HER2 positive and negative breast cancers. Oncologist. 2017; 22: 1316-24.
16. Liberati A, Altman DG, Tetzlaff J, Mulrow C, Gotzsche PC, Ioannidis JP, et al. The PRISMA statement for reporting systematic reviews and meta-analyses of studies that evaluate healthcare interventions: explanation and elaboration. BMJ. 2009; 339: b2700.

17. Zeng X, Zhang Y, Kwong JS, Zhang C, Li S, Sun F, et al. The methodological quality assessment tools for preclinical and clinical studies, systematic review and meta-analysis, and clinical practice guideline: a systematic review. J Evid Based Med. 2015; 8: 2-10.

18. Parmar MK, Torri V, Stewart L. Extracting summary statistics to perform meta-analyses of the published literature for survival endpoints. Stat Med. 1998; 17: 2815-34.

19. Tierney JF, Stewart LA, Ghersi D, Burdett S, Sydes MR. Practical methods for incorporating summary time-to-event data into meta-analysis. Trials. 2007; 8: 16.

20. Stang A. Critical evaluation of the Newcastle-Ottawa scale for the assessment of the quality of nonrandomized studies in meta-analyses. Eur J Epidemiol. 2010; 25: 603-5.

21. Wirsing AM, Rikardsen OG, Steigen SE, Uhlin-Hansen L, Hadler-Olsen E. Characterisation and prognostic value of tertiary lymphoid structures in oral squamous cell carcinoma. BMC clinical pathology. 2014; 14: 38.

22. Yamaguchi $K$, Ito $M$, Ohmura $H$, Hanamura $F$, Nakano $M$, Tsuchihashi $K$, et al. Helper T cell-dominant tertiary lymphoid structures are associated with disease relapse of advanced colorectal cancer. Oncoimmunology. 2020; 9: 1724763.

23. Yamakoshi Y, Tanaka H, Sakimura C, Deguchi S, Mori T, Tamura T, et al. Immunological potential of tertiary lymphoid structures surrounding the primary tumor in gastric cancer. International journal of oncology. 2020; 57: $171-82$.

24. Hiraoka N, Ino Y, Yamazaki-Itoh R, Kanai Y, Kosuge T, Shimada K. Intratumoral tertiary lymphoid organ is a favourable prognosticator in patients with pancreatic cancer. Br J Cancer. 2015; 112: 1782-90.

25. Calderaro J, Petitprez F, Becht E, Laurent A, Hirsch TZ, Rousseau B, et al. Intra-tumoral tertiary lymphoid structures are associated with a low risk of early recurrence of hepatocellular carcinoma. Journal of Hepatology. 2019; 70: $58-65$.

26. Posch F, Silina K, Leibl S, Mundlein A, Moch H, Siebenhuner A, et al. Maturation of tertiary lymphoid structures and recurrence of stage II and III colorectal cancer. Oncoimmunology. 2018; 7: e1378844.

27. Di Caro G, Bergomas F, Grizzi F, Doni A, Bianchi P, Malesci A, et al. Occurrence of tertiary lymphoid tissue is associated with T-cell infiltration and predicts better prognosis in early-stage colorectal cancers. Clin Cancer Res. 2014; 20: 2147-58.

28. Li K, Guo Q, Zhang X, Dong X, Liu W, Zhang A, et al. Oral cancer-associated tertiary lymphoid structures: gene expression profile and prognostic value. Clinical and Experimental Immunology. 2020; 199: 172-81.

29. Kuwabara S, Tsuchikawa T, Nakamura T, Hatanaka Y, Hatanaka KC, Sasaki $\mathrm{K}$, et al. Prognostic relevance of tertiary lymphoid organs following neoadjuvant chemoradiotherapy in pancreatic ductal adenocarcinoma. Cancer Sci. 2019; 110: 1853-62

30. Behr DS, Peitsch WK, Hametner C, Lasitschka F, Houben R, Schonhaar K, et al. Prognostic value of immune cell infiltration, tertiary lymphoid structures and PD-L1 expression in Merkel cell carcinomas. Int J Clin Exp Pathol. 2014; 7: 7610-21.

31. Figenschau SL, Fismen S, Fenton KA, Fenton C, Mortensen ES. Tertiary lymphoid structures are associated with higher tumor grade in primary operable breast cancer patients. BMC Cancer. 2015; 15: 101.

32. Trajkovski G, Ognjenovic L, Karadzov Z, Jota G, Hadzi-Manchev D, Kostovski $\mathrm{O}$, et al. Tertiary Lymphoid Structures in Colorectal Cancers and Their Prognostic Value. Open Access Macedonian Journal of Medical Sciences. 2018; 6: $1824-8$.

33. Lee HJ, Park IA, Song IH, Shin SJ, Kim JY, Yu JH, et al. Tertiary lymphoid structures: Prognostic significance and relationship with tumour-infiltrating lymphocytes in triple-negative breast cancer. Journal of clinical pathology. 2016; 69: 422-30

34. He W, Zhang D, Liu H, Chen T, Xie J, Peng L, et al. The High Level of Tertiary Lymphoid Structure Is Correlated With Superior Survival in Patients With Advanced Gastric Cancer. Frontiers in oncology. 2020; 10: 980.

35. Buisseret L, Garaud S, de Wind A, Van den Eynden G, Boisson A, Solinas C, et al. Tumor-infiltrating lymphocyte composition, organization and PD-1/ PD-L1 expression are linked in breast cancer. Oncoimmunology. 2017; 6: e1257452.

36. Schweiger T, Berghoff AS, Glogner C, Glueck O, Rajky O, Traxler D, et al. Tumor-infiltrating lymphocyte subsets and tertiary lymphoid structures in pulmonary metastases from colorectal cancer. Clinical and Experimental Metastasis. 2016; 33: 727-39.

37. Song IH, Heo SH, Bang WS, Park HS, Park IA, Kim YA, et al. Predictive Value of Tertiary Lymphoid Structures Assessed by High Endothelial Venule Counts in the Neoadjuvant Setting of Triple-Negative Breast Cancer. Cancer Res Treat. 2017; 49: 399-407.

38. Silina K, Soltermann A, Moch H, Line A, Van den Broek M. Tertiary lymphoid structures in chemotherapy-treated and untreated lung squamous cell carcinoma patients. Cancer Immunology Research. 2015; 3: B85.

39. Li Q, Liu X, Wang D, Wang Y, Lu H, Wen S, et al. Prognostic value of tertiary lymphoid structure and tumour infiltrating lymphocytes in oral squamous cell carcinoma. International journal of oral science. 2020; 12: 24 
40. Chao X, Liu L, Sun P, Yang X, Li M, Luo R, et al. Immune parameters associated with survival in metaplastic breast cancer. Breast cancer research : BCR. 2020; 22: 92.

41. Zhang WH, Wang WQ, Han X, Gao HL, Xu SS, Li S, et al. Infiltrating pattern and prognostic value of tertiary lymphoid structures in resected non-functional pancreatic neuroendocrine tumors. J Immunother Cancer. 2020; 8: e001188.

42. Chon HJ, Lee WS, Yang H, Kong SJ, Lee NK, Moon ES, et al. Tumor Microenvironment Remodeling by Intratumoral Oncolytic Vaccinia Virus Enhances the Efficacy of Immune-Checkpoint Blockade. Clin Cancer Res. 2019; 25: 1612-23.

43. Petitprez F, Meylan M, de Reyniès A, Sautès-Fridman C, Fridman W. The Tumor Microenvironment in the Response to Immune Checkpoint Blockade Therapies. Frontiers in immunology. 2020; 11: 784.

44. Petitprez F, de Reyniès A, Keung EZ, Chen TW-W, Sun C-M, Calderaro J, et al. $B$ cells are associated with survival and immunotherapy response in sarcoma. Nature. 2020; 577: 556-60.

45. Nagarsheth N, Wicha MS, Zou W. Chemokines in the cancer microenvironment and their relevance in cancer immunotherapy. Nat Rev Immunol. 2017; 17: 559-72.

46. Vilgelm A, Richmond A. Chemokines Modulate Immune Surveillance in Tumorigenesis, Metastasis, and Response to Immunotherapy. Frontiers in immunology. 2019; 10: 333.

47. Binnewies M, Roberts EW, Kersten K, Chan V, Fearon DF, Merad M, et al Understanding the tumor immune microenvironment (TIME) for effective therapy. Nat Med. 2018; 24: 541-50.

48. Anderson NM, Simon MC. The tumor microenvironment. Curr Biol. 2020; 30: R921-R5.

49. Cabrita R, Lauss M, Sanna A, Donia M, Skaarup Larsen M, Mitra S, et al. Tertiary lymphoid structures improve immunotherapy and survival in melanoma. Nature. 2020; 577: 561-5.

50. Akbani R, Akdemir Kadir C, Aksoy BA, Albert M, Ally A, Amin Samirkumar B, et al. Genomic Classification of Cutaneous Melanoma. Cell. 2015; 161: 1681-96.

51. Becht E, Giraldo NA, Lacroix L, Buttard B, Elarouci N, Petitprez F, et al. Estimating the population abundance of tissue-infiltrating immune and stromal cell populations using gene expression. Genome Biology. 2016; 17: 218.

52. Tirosh I, Izar B, Prakadan SM, Wadsworth MH, Treacy D, Trombetta JJ, et al. Dissecting the multicellular ecosystem of metastatic melanoma by single-cell RNA-seq. Science. 2016; 352: 189-96.

53. Engelhard VH, Rodriguez AB, Mauldin IS, Woods AN, Peske JD, Slingluff CL. Immune Cell Infiltration and Tertiary Lymphoid Structures as Determinants of Antitumor Immunity. The Journal of Immunology. 2018; 200: 432-42.

54. Yang J, Zhang S, Zhang L, Xie X, Wang H, Jie Z, et al. Lymphatic endothelial cells regulate B-cell homing to lymph nodes via a NIK-dependent mechanism. Cellular \& molecular immunology. 2019; 16: 165-77.

55. Kurtulus S, Madi A, Escobar G, Klapholz M, Nyman J, Christian E, et al. Checkpoint Blockade Immunotherapy Induces Dynamic Changes in PD-1(-)CD8(+) Tumor-Infiltrating T Cells. Immunity. 2019; 50: 181-94 e6.

56. Gunderson LL, Sargent DJ, Tepper JE, Wolmark N, O'Connell MJ, Begovic M, et al. Impact of $\mathrm{T}$ and $\mathrm{N}$ Stage and Treatment on Survival and Relapse in Adjuvant Rectal Cancer. Journal of Clinical Oncology. 2004; 22: 1785-96. 